\title{
KANDUNGAN TOTAL FENOLIK DAN UJI TOKSISITAS DAUN MUHARANG BAWINE (Dendrophthoe falcate (Lf) Etinggsh) DENGAN METODE BLST (Brine Shrimp Lethality Test)
}

\author{
Merlin $^{1 *}$, Max R.J. Runtuwene ${ }^{1}$, Vanda S. Kamu ${ }^{1}$ \\ ${ }^{1}$ Jurusan Kimia Fakultas Matematika dan Ilmu Pengetahuan Alam Universitas Sam Ratulangi, \\ Jl. Kampus Unsrat, Kleak, Manado 95115 Sulawesi Utara
}

\begin{abstract}
ABSTRAK
Penelitian ini bertujuan untuk,menentukan kandungan total fenolik, dan mengetahui tingkat toksisitas ekstrak muharang bawine (Dendrophthoefalcate (Lf) Etinggsh) dengan Metode BLST (Brine shrimp lethality test) dari beberapa pelarut.Uji toksisitas dengan menggunakan udang $A$. salina leach.Serbuk daun muharang bawine diekstraksi dengan cara maserasi bertingkat dengan menggunakan pelaut $n$-heksan, etil asetat dan metanol selama $3 \times 24$ jam sehingga diperoleh ekstrak kental. Penentuankandungan total fenolik diukur dengan metode Folin-Ciocalteu dan nilai $\mathrm{LC}_{50}$ dihitung dengan menggunakan SPSS 15.0.Kandungan total fenolik tertinggi terdapat pada hasil maserasi bertingkat ekstrak metanol, diikuti dengan hasil maserasi bertingkat ekstrak etil asetat dan hasil maserasi bertingkat ekstrak n-heksan. Hasil LC $_{50}$ paling terbaik terdapat pada hasil maserasi bertingkat ekstrak metanol, kemudian diikuti dengan hasil maserasi bertingkat ekstrak etil asetat dan hasil maserasi bertingkat ekstrak n-heksan.
\end{abstract}

Kata kunci: Daun muharang bawine, fitokimia, fenolik, BLST.

\begin{abstract}
This study aims to determine the total phenolic content, and determine the toxicity level of muharang bawine extract (Dendrophthoe falcate (LF) Ettingsh) with the BLST (Brine Shrimp Lethality Test) method of several solvents. Toxicity test using A. salina Leach shrimp. Leaf Extract Muharang Bawine was extracted by multilevel maceration using n-hexane, ethyl acetate and methanol for $3 \times 24$ hours for thick extracts. Determination of total phenolic content was measured by the Folin-Ciocalteu method and LC50 values were calculated using SPSS 15.0. The highest total phenolic content was found in the results of maceration of methanol extract multilevel, followed by maceration results of multilevel ethyl acetate extract and maceration results of $n$-hexane extract. The best LC50 results were found in the results of maceration of methanol extract multilevel, then followed by maceration results of multilevel extract of ethyl acetate and maceration results of $n$-hexane extract.
\end{abstract}

Keywords: muharang bawine leaf, phytochemical, phenolic, BLST.

\section{PENDAHULUAN}

Indonesia adalah negara yang kaya akan keanekaragaman hayati, salah satunya yaitu tanaman obat yang masih banyak dimanfaatkan oleh masyarakat. Tanaman Muharang Bawine (Dendrophthoe falcate (Lf) etinggsh), merupakan jenis benalu yang menempel pada pohon Jambu Air. Ada beberapa jenis dari kelompok benalu juga dapat bermanfaat sebagai tumbuhan tanaman obat salah satunya yaitu tanaman muharang bawine. Berdasarkan informasi yang diperoleh khususnya masyarakat Tagulandang, tanaman muharang bawine (Dendrophthoe falcate (Lf) etinggsh) dapat digunakan sebagai salah satu tanaman obat antikanker (Runtuwene dkk., 2019). Pada umunya tumbuhan mengandung metabolit sekunder yang dapat berpotensi sebagai antioksidan, di antaranya adalah alkaloid, flavonoid, senyawa fenol, steroid, dan terpenoid (Marliana, 2007). Salah satu metode yang digunakan untuk penemuan obat tradisional adalah metode ekstraksi. Dalam sampel daun muharang bawine masih terdapat berbagai kelompok senyawa metabolit sekunder sehingga perlu dilakukan pemisahan senyawa melalui proses maserasi bertingkat. Ekstraksi merupakan proses pemisahan bahan dari campurannya dengan menggunakan pelarut yang sesuai (Fajarullah, 2014).

Skrining fitokimia merupakan salah satu upaya yang dapat dilakukan untuk mengetahui fitokimia atau bahan aktif yang merupakan

\footnotetext{
Korespondensi:

Telepon: +62 821-8776-7013

Email: merlinmasanggelo1@gmail.com

DOI: https://doi.org/10.35799/cp.13.1.2020.28830
} 
metabolit sekunder pada tumbuhan. Bahan aktif ini dapat berfungsi sebagai pertahanan diri tumbuhan terhadap lingkungan, penyakit dan serangan pemangsa (Kristanti dkk., 2008).

Untuk mengetahui suatu tanaman memiliki potensi sebagai anti kanker, maka perlu dilakukan penelitian awal. Salah satu metode awal untuk uji sitotoksik adalah Brine Shrimp Lethality Test (BSLT). BSLT merupakan salah satu metode yang banyak digunakan untuk pencarian senyawa anti kanker baru yang berasal dari tanaman. Metode BSLT telah terbukti memiliki korelasi dengan aktivitas antikanker. Selain itu, metode ini juga mudah dikerjakan, murah, cepat, dan cukup akurat (Mayer dkk., 1982).

Berdasarkan penelusuran literature belum ada penelitian tentang uji toksisitas daun muharang bawine. Oleh sebab itu peneliti ingin melakukan uji tentang kandungan total fenolik dan uji toksisitas dari daun muharang bawine (Dendrophthoe falcate (Lf) Etinggsh), dengan metode BLST (Brine shrimp lethality test) dari beberapa pelarut dan uji golongan senyawa aktif lainnya.

\section{BAHAN DAN METODE}

\section{Alat dan bahan}

Peralatan yang digunakan dalam penelitian ini adalah neraca analitik, Alumunium foil, desikator, alat - alat gelas, neraca analitik, oven, blender, ayakan 65 mesh, kertas saring, waterbath, rotary evaporator, spektrofotometer UV-VIS, spatula, lampu pijar 40 watt, wadah bening, blender, pipet mikro, pipet tetes, kaca pembesar. Bahan yang digunakan dalam penelitian yaitu daun muharang bawine yang diperoleh dari Desa Tagulandang, $n$-heksan, etil asetat, metanol reagen Folin-Ciocalteu, larutan $\mathrm{H}_{2} \mathrm{SO}_{4}$ pekat, pereaksi Mayer dan Dragendorff, kloroform, amonia, $\mathrm{HCl}$ pekat, $\mathrm{HCl} \mathrm{I} \mathrm{N,} \mathrm{FeCl}_{3}$ $1 \%, \mathrm{FeCL}_{3} 5 \%$, asam asetat glasial, $\mathrm{Na}_{2} \mathrm{CO}_{3}$, aquades, garam tak beryodium, telur udang $A$. salina.

\section{Preparasi sampel}

Sampel dari daun Muharang Bawine yang diperoleh terlebih dahulu dibersikan dari kotoran yang menempel dipotong - potong dan dioven selama 3 hari pada suhu $40^{\circ} \mathrm{C}$ sampai daun tersebut kering, selanjutnya diblender dan disaring dengan menggunakan ayakan 65 mesh sehingga diperoleh serbuk daun muharang bawine yang siap dimaserasi.

\section{Kadar air}

Sebanyak 2 gram serbuk muharang bawine ditimbang secara teliti dalam cawan porselin yang telah dikeringkan dan diketahui berat cawan tersebut. Cawan kemudian dikeringkan dalam oven pada suhu $105-110^{\circ} \mathrm{C}$ selama 3 jam. Cawan dikeluarkan dan didinginkan dalam desikator, kemudian ditimbang. Pengeringan dilanjutkan lagi dan setiap setengah jam didinginkan dan ditimbang sampai diperoleh bobot yang konstan (AOAC, 1999).

Kadar air dihitung dengan persamaan sebagai berikut:

$$
\% \text { Kadar Air }=\frac{(A+B)-C}{B} \times 100 \%
$$

Keterangan: $\mathrm{A}=$ berat wadah; $\mathrm{B}=$ berat sampel sebelum dipanaskan; $\mathrm{C}=$ berat sampel + wadah setelah dipanaskan

\section{Ekstraksi}

Ekstraksi daun muharang bawine dilakukan dengan cara maserasi menggunakan pelarut $n$-heksan etil asetat, dan metanol. Ditimbang sebanyak $200 \mathrm{~g}$ simplisia daun muharang bawine lalu ditambahkan pelarut 800 $\mathrm{mL}$ hingga simplisia terendam seluruhnya. Ekstraksi dilakukan selama 3×24 jam terlindung dari cahaya dan dilakukan pengadukan setiap 24 jam. Pada hari ke 2 dan ke 3 pelarut disaring untuk dilakukan remaserasi sehingga diperoleh 3 filtrat untuk setiap pelarut. Filtrat kemudian dievaporasi dengan rotari evaporator sehingga diperoleh ekstrak kental $n$-heksan, etil asetat dan metanol dari daun muharang bawine.

\section{Skrining fitokimia}

Ekstrak kental dari beberapa pelarut dianalisis dengan dilakukan uji kandungan, fenolik, alkaloid, tanin, flavanoid, steroid/ trirerpenoid.

\section{Uji fenolik}

Sebanyak $1 \mathrm{~mL}$ ekstrak daun Muharang Bawine dari hasil maserasi yaitu $n$-heksan, etil asetat dan metanol masing-masing sampel dimasukan dalam tabung reaksi, kemudian ditambahkan 2-3 tetes besi (III) klorida $\left(\mathrm{FeCL}_{3}\right)$ 5\%. Ekstrak positif fenol apabila menghasilkan warna biru kehitaman (Harborne, 1987).

\section{Uji alkaloid}

Pengujian alkaloid ditentukan dengan metode Harborne (1996). Pengujian alkaloid sebanyak $40 \mathrm{mg}$ ekstrak ditambahkan $2 \mathrm{~mL}$ kloroform dan $2 \mathrm{~mL}$ amonia lalu disaring. Filtrat 
ditambahkan 3 sampai 5 tetes $\mathrm{H}_{2} \mathrm{SO}_{4}$ pekat lalu dikocok hingga terbentuk dua lapisan. Fraksi asam diambil, kemudian ditambahkan pereaksi mayer dan dragendorff masing-masing 4-5 tetes. Apabila terbentuk endapan menunjukkan bahwa sampel tersebut mengandung alkaloid, dengan pereaksi mayer memberikan endapan berwarna putih, dan pereaksi dragendorff memberikan endapan berwarna kuning-merah.

\section{Uji flavonoid dengan $\left(\mathrm{H}_{2} \mathrm{SO}_{4}\right) 2 \mathrm{~N}$}

Sebanyak $1 \mathrm{~mL}$ ekstrak sampel daun muharang bawine dimasukkan ke dalam tabung reaksi, kemudian ditambahkan asam sulfat $\left(\mathrm{H}_{2} \mathrm{SO}_{4}\right) 2 \mathrm{~N}$ sebanyak 2 tetes dan dikocok kuat. Sampel positif mengandung flavonoid bila larutan mengalami perubahan warna yang sangat mencolok menjadi warna kuning, merah, atau coklat. (Harborne, 1996).

\section{Uji tanin}

Diambil $1 \mathrm{~mL}$ ekstrak daun muharang bawine dan dimasukkan ke tabung reaksi dan ditambahkan 2-3 tetes $\mathrm{FeCl}_{3}$ 1\%. Sampel mengandung tanin bila terjadi perubahan warna dari warna awal hijau muda menjadi hijau kehitaman. (Harborne, 1996).

\section{Pengujian steroid/triterpenoid}

Sebanyak $40 \mathrm{mg}$ ekstrak ditambahkan $\mathrm{CH}_{3} \mathrm{COOH}$ glasial sebanyak 10 tetes dan 2 tetes $\mathrm{H}_{2} \mathrm{SO}_{4}$. Larutan dikocok perlahan dan dibiarkan selama beberapa menit. Steroid memberikan warna biru atau hijau, sedangkan triterpenoid memberikan warna merah atau ungu. (Harborne, 1987).

\section{Penentuan total fenolik}

Kandungan total fenolik ekstrak nheksan, etil asetat, metanol, dari hasil maserasi bertingkat daun muharang bawine ditentukan dengan metode (Jeong dkk., 2004). Sebanyak 0,1 $\mathrm{mL}$ larutan ekstrak dari hasil maserasi bertingkat ditambahkan $0,1 \mathrm{~mL}$ reagen Folin-Ciocalteu $50 \%$. Kemudian divorteks, lalu ditambahkan 2 $\mathrm{mL}$ larutan natrium karbonat $\left(\mathrm{Na}_{2} \mathrm{CO}_{3}\right) 2 \%$. Selanjutnya, campuran diinkubasi dalam ruangan gelap selama 30 menit. Diukur absorbansi pada panjang gelombang $750 \mathrm{~nm}$ menggunakan spektrofotometer UV-Vis. Kandungan total fenolik dinyatakan sebagai mg ekuivalen asam galat/g ekstrak.
Uji toksisitas menggunakan metode brine shrimp lethality test (BLST) penetasan larva udang Artemia salina leach

Larva udang Artenemia salina leach terendam dalam air laut. Air laut yang digunakan merupakan air laut sintetik yang dibuat dengan cara melarutkan garam non yodium sebanyak 20 gram dalam $1000 \mathrm{~mL}$ aquades, selama 3X24 jam dalam gelas piala yang besar, di tutup dengan aluminium foil. Suhu penetasan dan $\mathrm{pH}$ dikontrol. Suhu penetasan telur adalah $24^{\circ} \mathrm{C}$ dan pH \pm 6 -7 (Meyer dkk., 1982).

\section{Uji toksisitas}

Sebanyak 10 ekor larva Udang Artenemia salina leach yang sehat berumur 48 jam dimasukan dalam gelas aqua. Larutan ekstrak pada masing- masing gelas aqua kemudian diuji dengan konsentrasi 500 ppm, 250 ppm, 125 ppm, dan $62,5 \mathrm{ppm}$. Pengamatan dilakukan selama 24 jam dengan menghitung jumlah larva yang mati dari total larva yang dimasukkan dalam gelas aqua. Penghitungan $\mathrm{LC}_{50}$ dengan menggunakan analisis probit dari data persen dengan selang kepercayaan 95\% pada program SPSS 15.0 .

Data dari nomor probit dimasukan ke dalam tabel. Sumbu X adalah konsentrasi log dan sumbu Y adalah persen kematian

$\%$ Kematian $=\frac{\text { Jumlah larva yang mati }}{\text { Total larva }} \times 100 \%$

Setelah itu, hasil analis ditempatkan ke dalam tabel dan hasil dari regresi $\mathrm{Y}=\mathrm{AX}+\mathrm{B}$. Nilai $\mathrm{LC}_{50}$ diperoleh dengan memasukan nilai $\mathrm{Y}$ $=50$, kemudian nilai $\mathrm{LC}_{50}$ diambil. Apabila pada kontrol ada udang yang mati, persentase kematian udang larva Artenemia Salina Leach ditentukan dengan rumus Abbo's sebagai berikut:

\%Kematian

\%kematian pada uji-\%kematian pada kontrol 100-\%kematian pada kontrol

Hasil yang diperoleh dinyatakan sebagai nilai $\mathrm{LC}_{50}$ ekstrak uji, yaitu jumlah konsentrasi uji yang diperoleh dapat menyebabkan kematian larva udang sejumlah $50 \%$ setelah masa inkubasi 24 jam yang dihitung dengan menggunakan persamaan regresi dengan menghubungkan pengaruh konsentrasi sampel (logaritma nilai konsentrasi terhadap persen kematian mortalitas larva uji yang dikonversi dalam nilai probit. 


\section{HASIL DAN PEMBAHASAN}

\section{Kadar air}

Kadar air ini dilakukan agar mengetahui banyaknya kadar air yang terkandung dalam sampel. Pengujian kadar air ini dilakukan sebanyak 3 kali pengulangan, pengujian kadar air yang pertama yaitu 5,8782, pada pengujian kedua yaitu 5,7873, pada pengujian ketiga yaitu 5,4292 sehingga memperoleh rata-rata yaitu 5,6969. Kadar air pada sampel tanaman muharang bawine ini telah memenuhi syarat untuk kadar air yang ditetapkan yaitu kadar air yang dibawah batas maksimum $10 \%$, hal ini bertujuan agar supaya sel-sel mikro organisme yang masih terdapat dalam kadar air yang tinggi menjadi lebih kecil, sehingga akan mempengaruhi senyawa-senyawa kimia yang ada dalam sampel.

\section{Skrining fitokimia}

Pengujian fitokimia dilakukan untuk mengetahui kandungan senyawa aktif yang terdapat pada tanaman. Uji fitokimia pada penelitian ini dilakukan terhadap daun muharang bawine dari hasil maserasi bertingkat ekstrak $n$ heksan, ekstrak etil asetat dan ekstrak metanol. pada hasil maserasi bertingkat ekstrak $n$-heksan, etil asetat dan metanol Hasil skrining fitokimia dari ekstrak $n$-heksan, etil asetat dan metanol dapat dilihat pada Tabel 1.

Tabel 1. Hasil Skrining Fitokimia

\begin{tabular}{|c|c|c|c|}
\hline Senyawa & $\begin{array}{l}\text { Eksktrak } \\
n \text {-heksan }\end{array}$ & $\begin{array}{l}\text { Ekstrak } \\
\text { etil asetat }\end{array}$ & $\begin{array}{l}\text { Ekstrak } \\
\text { metanol }\end{array}$ \\
\hline Fenolik & + & + & + \\
\hline Alkaloid & + & + & + \\
\hline Flavanoid & + & + & + \\
\hline Tanin & + & + & + \\
\hline Steroid & + & - & + \\
\hline Triterpenoid & - & + & - \\
\hline
\end{tabular}

Berdasarkan hasil skrining fitokimia, diketahui bahwa hasil maserasi bertingkat ekstrak $n$-heksan, etil asetat, dan metanol mengandung senyawa fenolik. Hal ini terlihat dari masing-masing sampel yang mengalami perubahan warna dari warna awal hijau menjadi warna biru kehitaman. Pada hasil skrining hasil maserasi bertingkat ekstrak $n$-heksan, etil asetat, dan metanol diketahui mengandung senyawa alkaloid. Hal ini terlihat dari endapan yang terbentuk pada masing-masing sampel pada pereaksi mayer memberikan warnah putih dan pereaksi Dragendroff memberikan endapan berwarna kuning kemerahan. Pada hasil skrining hasil maserasi bertingkat ekstrak $n$-heksan, etil asetat, dan metanol diketahui mengandung senyawa flavonoid. Hal ini terlihat dari masingmasing sampel yang mengalami perubahan warna dari warna awal hijau menjadi warna kuning. Pada hasil skrining hasil maserasi bertingkat ekstrak $n$-heksan, etil asetat, dan metanol diketahui mengandung senyawa tanin. Hal ini dapat dilihat dari masing-masing sampel yang mengalami perubahan warna dari warna awal hijau menjadi hijau kehitaman.

Pada hasil skrining maserasi bertingkat ekstrak $n$-heksan, dan metanol diketahui mengandung senyawa steroid dan ekstrak etil asetat mengandung senyawa triterpenoid. Hal ini dapat dilihat dari perubahan warna masingmasing sampel pada steroid memberikan warna biru dan triterpenoid memberikan warna ungu. Pengujian fitokimia yang telah dilakukan menunjukkan bahwa ekstrak daun muharang bawine memiliki kandungan metabolit sekunder berupa fenolik, alkaloid, flavonoid, tanin, steroid dan triterpenoid. Keberadaan metabolit sekunder tersebut menunjukkan bahwa daun Muharang Bawine mempunyai efek farmakologis dan berpotensi untuk dijadikan sebagai bahan obatobatan.

\section{Kandungan total fenolik}

Penentuan kandungan total fenolik dilakukan untuk mengetahui total kandungan senyawa fenolik yang terdapat dalam hasil maserasi bertingkat $n$-heksan, etil asetat dan metanol. Penentuan kandungan fenolik dinyatakan sebagai $\mathrm{mg}$ ekivalen asam galat/g ekstrak. Hasil kandungan total fenolik hasil maserasi bertingkat ekstrak $n$-heksan, etil asetat dan metanol dapat dilihat pada Gambar 1.

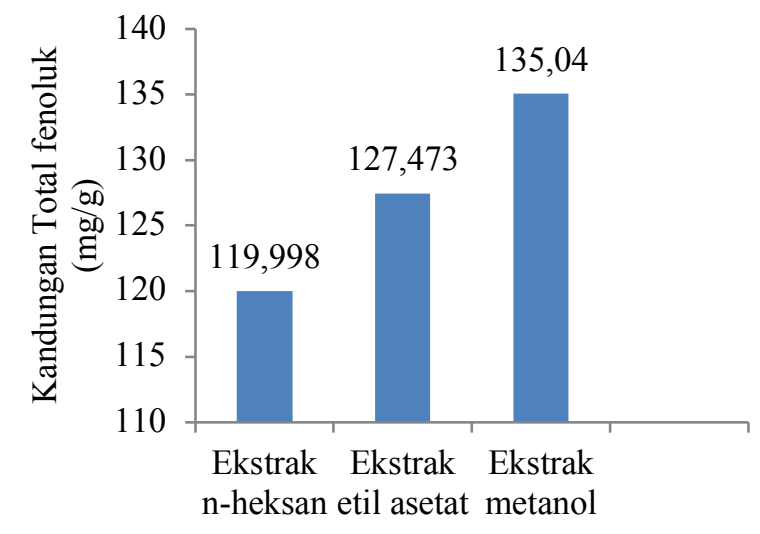

Gambar 1. Kandungan total fenolik ekstrak maserasi bertingkat $n$-heksan, etil asetat, dan metanol 
Berdasarkan Gambar 1. Dapat diketahui bahwa hasil maserasi bertingkat ekstrak $n$ heksan, etil asetat, dan metanol daun muharang bawine ini memiliki kandungan fenolik yang paling tinggi yaitu pada ekstrak metanol 135, 040 $\mathrm{mg} / \mathrm{g}$, diikuti hasil maserasi bertingkat ekstrak etil asetat yaitu 127, $473 \mathrm{mg} / \mathrm{g}$ dan $n$-heksan yaitu $119,998 \mathrm{mg} / \mathrm{g}$. Kandungan total fenol yang tinggi pada hasil maserasi bertingkat metanol menunjukan bahwa senyawa fenol merupakan senyawa yang bersifat polar. Hal ini karena Pelarut metanol bersifat polar sehingga dapat melarutkan senyawa fenolik yang lebih banyak sehingga menunjukkan sebagian besar senyawa fenolik merupakan senyawa yang bersifat polar (Harborne, 1987).

\section{Uji toksisitas dengan menggunakan metode BLST}

Dari hasil toksisitas pada table 4. Menunjukan bahwa semakin besar konsentrasi suatu ekstrak maka sifat toksinya akan semakin tinggi, sehingga kematian larva di pengaruhi oleh peningkatan konsetrasi dari sampel (Harborne, 1987). Tingkat kematian larva Artemia Salina Leach dipengaruhi banyaknya kandungan fenolik pada ekstrak uji. Hal ini dapat dilihat pada nilai $\mathrm{LC}_{50}$ ekstrak metanol yaitu 38,815 ppm, ekstrak etil asetat yaitu 54,827 ppm dan ekstrak nheksan yaitu 58, 479 ppm.Semakin kecil nilai $\mathrm{LC}_{50}$ dari suatu sampel maka semakin tinggi senyawa bioktifnya. Tingginya aktivitas senyawa bioaktif dari hasil maserasi bertingkat ekstrak metanol terhadap larva Artemia slina leach disebabkan adanya kandungan senyawa fenolik yang cukup tinggi (Harborne,1996).

Tabel 2. Nilai $\mathrm{LC}_{50}$ dari hasil maserasi bertingkat daun muharang bawine

\begin{tabular}{ll}
\hline Sampel & Nilai $\mathrm{LC}_{50}(\mathrm{ppm})$ \\
\hline$n$-heksan & 58,479 \\
Etil asetat & 54,827 \\
Metanol & 38,815 \\
\hline
\end{tabular}

Selain fenolik metabolisme sekunder yang lain juga seperti flavonoid, alkaloid, tanin, steroid/triterpenoid dapat memberikan aktivitas toksisitas yaitu dengan bertindak sebagai racun. Apabila senyawa tersebut masuk kedalam tubuh larva alat pencernaanya akan terganggu dan dapat menghambat reseptor perasa pada mulut larva. Hal ini dapat mengakibatkan larva gagal mendapat stimulus rasa sehingga tidak mampu mengenali makananya sehingga larva akan mati kelaparan. Suatu ekstrak menunjukan aktivitas ketoksikan dalam BLST jika ekstrak dapat menyebabkan kematian 50\% hewan uji pada konsentrasi kurang dari $1000 \mu \mathrm{g} / \mathrm{mL}$ (Mayer, 1982). Berdasarkan data hasil pengujian yang kemudian diolah menggunakan analisis probit $\mathrm{LC}_{50}$ hasil maserasi bertingkat ekstrak metanol yaitu 38,815 ppm dari pernyataan diatas, maka hal ini menunjukan bahwa hasil maserasi bertingkat dari ekstrak metanol daun muharang bawine bersifat toksik.

\section{KESIMPULAN}

Kandungan total fenolik tertinggi terdapat pada hasil maserasi bertingkat ekstrak metanol daun Muharang Bawine, diikuti dengan hasil maserasi bertingkat ekstrak etil asetat daun Muharang Bawine dan hasil maserasi bertingkat ekstrak n-heksan daun Muharang Bawine 2. Hasil $\mathrm{LC}_{50}$ paling toksik terdapat pada hasil maserasi bertingkat ekstrak metanol, kemudian diikuti dengan hasil maserasi bertingkat ekstrak etil asetat dan hasil maserasi bertingkat ekstrak n-heksan.

\section{DAFTAR PUSTAKA}

AOAC. 1995. Official methods of analysis. Associationt of Offical Analytical Chemist. Washington DC, USA.

Fajarullah, A., Irawan, H. \& Pratomo, A. 2014. Ekstraksi senyawa metabolit sekunder lamun thalassodendron ciliatum pada pelarut berbeda. Repository UMRAH.

Harborne, J.B. 1999. Metode fitokimia: Penuntun cara modern menganalisa tumbuhan. Bandung: Intitut Teknologi Bandung.

Harborne, J.B. 1996. Metode fitokimia. Terbitan Kedua. Bandung: ITB.

Jeong, S.M., Kim, S.Y., Kim, D.R., Jo, S.C., Nam, K.C., Ahn, D.U. \& Lee, S.C. 2004. Effect of heat treatment on the antioxidant activity of extracts from citrus peels. Journal of Agricultural and Food Chemistry. 52(3), 3389-3393.

Kristianti, A.N., Aminah, N., Tanjung, M. \& Kurnia, B. 2008. Buku ajar fitokimia. Surabaya: Jurusan Kimia Laboratorium Kimia Organik FMIPA Universitas Airlangga.

Marliana, E. 2007. Analisis senyawa metabolit sekunder dari batang Spatholobus ferrugineus (Zoll \& Moritzi) benth yang 
berfungsi sebagai antioksidan. Jurnal Penelitian MIPA. 1(4), 23-25.

Mayer, B.N., Ferrigini, N.R., Putnam., J.E., Jacobsen, L.B., Nichols, D.E. \& Mc Laughlin, J.L. 1982. Brine shrimp: A Convenient General Bioassay for Active Plant Constituents. Journal of Planta Medica. 45(5), 31-45. 